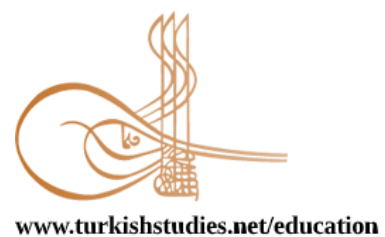

Turkish Studies - Educational Sciences

\title{
Çocuk Kavramının Çocuk Gelişimi Programı Öğrencileri Gözünden İncelenmesi*
}

\author{
Investigation of the Concept of Child through the Wievs of the Child Development Program \\ Students
}

\author{
A. Seda Saracaloğlü ${ }^{* *}$ Hilal Hatice Ülkü ${ }^{* * * *}$ - Ümit Gözel ${ }^{* * * *}$
}

\begin{abstract}
In this study, it is aimed to reveal what the concept of child is in the wievs of vocational high school child development program students. Therefore, case study, one of the qualitative research patterns, was used. Research was carried out with 13 child development associate degree students studying at a public university in the Aegean region of Turkey during the 2018-2019 spring semester. Participants were determined according to the critical case sampling method, which is one of the purposeful sampling methods. 13 participants from 2nd grade students (6 at the lower academic level and 7 at the upper academic level) were interviewed. In order to obtain the opinions of the participants, 4 questions were determined. The interviews were held face to face and the data was obtained with the semi-structured interview form. The data obtained from the interviews were written on the interview form and about 25 pages of raw data were reached. The interview data were coded by 3 different people. Findings were tried to be explained within the scope of 4 themes emerging in line with the data obtained from the codings. As a result, while the participants tried to describe the concept of child with the terms bearing different meanings, they think that the society does not have the desired information regarding children and child development and it does not show the necessary respect to children. In addition, it was found out that the participant do not have detailed and thorough information on child development, even though they have partial knowledge on children and their development, and that their fundamental objective in choosing and studying this program is the sympathy for children.
\end{abstract}

Structured Abstract: Interesting in the definition of the child has always drawn the attention of philosophers and educators from past to present (Erdiller-Yatmaz, Erdemir \& Erbil, 2018b). First time in history, Aries (1962) examined the definition of the child and childhood, and since that day the child has

\footnotetext{
${ }^{*} 3^{\mathrm{RD}}$ International Congress on Woman and Child Health and Education. 18 Nisan 2019, Trabzon-Oral Presentation.

** Prof. Dr. Aydın Adnan Menderes Üniversitesi, Eğitim Fakültesi, Eğitim Programları ve Öğretim Anabilim Dalı

Prof. Aydin Adnan Menderes University, Faculty of Education, Curriculum and Instruction.

ORCID 0000-0001-7980-0892

sedasaracal@gmail.com

***ö̈̆gr. Gör. Aydın Adnan Menderes Üniversitesi, Buharkent Meslek Yüksekokulu, Çocuk Gelişimi Programı Lecturer, Aydin Adnan Menderes University, Buharkent Vocational High School, Child Development Program. ORCID 0000-0003-1780-3531

hilal.gulludere@adu.edu.tr

*****̈̈̆r. Aydın Adnan Menderes Üniversitesi, Öğrenci İşleri Daire Başkanlığ

Teacher, Aydin Adnan Menderes University, Student Affairs Office.

ORCID 0000-0002-6391-0998

umit.gozel@adu.edu.tr

Cite as/ Atıf: Saracaloğlu, A. S. \& Ülkü, H. H. \& Gözel, Ü. (2020). Çocuk kavramının çocuk gelişimi programı öğrencileri gözünden incelenmesi. Turkish Studies - Education, 15(3), 2173-2189. https://dx.doi.org/10.29228/TurkishStudies.41588

Received/Geliş: 03 February/Şubat 2020

Accepted/Kabul: 24 June/Haziran 2020

Copyright (C) INTAC LTD, Turkey

Checked by plagiarism software

Published/Yayın: 25 June/Haziran 2020

CC BY-NC 4.0
} 
taken part in the research as a topic (Erdiller-Yatmaz, Erdemir \& Erbil, 2018b). Also, Aries supports that childhood as an invention was discovered by the Renaissance. He says that in the Middle Ages there was no concept of childhood, children shared the adult world in all aspects, and children were not in any field of art at that time was evidence of a transition from infancy to adulthood (Onur, 2005). Heywood (2003) emphasized that children are not a model of the parent and explained that the expression of children as pure, innocent and weak is related to the cultural and historical situations. With developing the world, the child is accepted as a separate subject from the adult (Düzcan, 2017). Considering children as a separated class, how they are perceived, and the expectations from children indicate the role given to the child in a society (Kaya, Vural \& Aydın, 2016).

From a developmental perspective, the child is the essence of the human being and reflects the capacity in the process of being human formation. Childhood is a period with unique and exclusive features that must be assessed from adulthood separately. Childhood represents "what could be"; in other words, it signifies the future (Erdiller-Yatmaz, Erdemir \& Erbil, 2018b). Since child education is the most important assurance of a society, it is necessary for a bright future (Kuyucu, Şahin \& Kapicioğlu, 2013). This situation makes the role of preschool institutions, where children begin their educational life, considerable important (Duran \& Dağlıoğlu, 2017).

While examining the literature, it could be seen that studies on concepts as children and children's games (Aydoğdu \& Ayanoğlu, 2019; Demirbaş, 2015; Egemen, Adil \& Y1lmaz, 2004; Ergin, Şahin \& Erişen, 2013; Giren, 2016; Kabaday1, 2016; Saban \& Özcan, 2018; Kuyucu, Şahin \& Kapıcıŏlu, 2013; Pesen, 2015; Ünal, Erdoğan \& Demirhan, 2016), child development (Ahioğlu, 2008), children's rights (Kurtdede Özyürek \& Özaydın, 2019), child participation (Bektaş, Yavaş \& Can, 2018), child and democracy (Sadık \& Sarı, 2012), child and teacher (Akgün, 2016), children's literature and books (Hasırc1, 2013; Pektaş \& Bencik Kangal, 2015; Ulusoy \& Altun, 2018) and child abuse (Uysal Bayrak, 2019) were carried out. As there is not research on evaluating the concept of the child from the perspectives of the students of the child development programme with dissimilar dimensions, this research will contribute to the literature.

This study aims to understand the thoughts about children from the perspectives of the students of the child development programme and examine their perceptions about children. With this purpose, this research was sought to answers about questions such as "what does the concept of the child mean?", "how is the value given to a child in a society?", "what are developmental differences between adults and children?", "what is the reason for choosing the programme?".

This research is a case study developed through qualitative research. It was carried out by taking into account the opinions of 13 second-grade child development students studying at a public university in the Aegean in the spring term of 2018-2019. In selecting the interviewed participants, an appropriate sample was created in terms of time, effort and cost convenience, especially because the research was limited to a specific region and provided extensive information. The data was collected through a semi-structured interview form created by the researchers. In the creation of the interview form, a literature review was conducted on the child, the child development and child development program, a pilot study was carried out with the interview questions, which were created after approval by two experts, and finally the form consisting of the 4 open-ended questions was created according to the feedbacks. As a result of the descriptive analysis of the data, different categories and codes were reached 4 themes which are the child, the value given to the child, the adult-child model and the purpose of coming to the programme.

The participants explained the concept of the child; games, toys, sandcastles, cartoons, love, peace, happiness, innocence, joy in the house, the future of our society, purity, cleanliness, naturalness, smiles, creativity and unlimited imagination, the past of the elders, the most beautiful and the special period of human life. In the study of Kuyucu, Şahin and Kapıcıoğlu (2013), the child's concept was explained with a similar concept such as "dough, an empty cassette, mirror, flower, angel, food of the soul, tree, computer, camera and ribbon, love, star, Notebook, diamond and jewel, unfrozen concrete, hungry person, sponge, unopened clean letter, secret box, treasure, future, sunflower, cute monkey, table, technology, rainbow, earth, sanctuary, sparkle, water, yeast, dream, dragon, Food, harvest, smile, comedian, energy bomb, peace". Çelik and Çat (2018) also achieved similar results. The concept of the child was generally explained with innocence, the good to be enlarged, the peace of the house, the mirror of the house, the ore, the unshaped dough, the responsibility, the risk etc. 
Regarding the values given to the child in Turkish society, the participants stated that the child was not given the necessary value by society generally. They explain the reason why the value the child receives is sufficient in a conscious society and family structure. In the results of the study of Tezel Şahin and Cevher (2007), according to compared to the past, parent-child communication is improved and more positive attitudes towards the child are started to be displayed; however, it is understood that there is still an attempt to impose a utilitarian value on children as well as parents attach more value to the child's education and personal development more than the socio-economic level.

It was found that almost all participants believed that the child was an adult model. In the study of Erdiller-Yatmaz, Erdemir and Erbil (2018b), the child cannot be the same as an adult as the development of a child is based on reasons such as development, body, need for care and addiction, learning and experience, behavior and restraint, resistance and persistence, expression and determination of their needs.

The result of the participants' choosing of the programme are child love, ideals, the first stage of their career plans, and they prefer this department because of their score or employment opportunities. While Thomson et al. (2011) explained the reasons for choosing a teaching profession as a socio-cultural context, Holland (1985) and Roe (1957) found that personal needs and preferences developed due to the interplay of family, environment and genetic factors when choosing a career.

As a result, most of the participants explained the concept of the child with positive expressions. While participants indicated that the value the child receives as a society has some shortcomings, they stated that adults are role models for children. It turned out that the purpose of the participants' visit was to love children. Given these results, some suggestions can be made.

- The willingness, professional susceptibility and professional attitude of the students who come to the program should be determined and supported by organizing various scientific activities such as seminars.

- For students with different goals to participate in the program, training / activities can be organized that promote love for children.

- Considering the opinions of the students studying the program on child development (cognitive, affective, etc.), it may be recommended to treat the problems and teaching related to child development more carefully.

Keywords: Education Sciences, Child, Child Concept, Child Development, Child Development Program

Öz: $\mathrm{Bu}$ araştırmada çocuk kavramının meslek yüksekokulları Çocuk Gelişimi programı öğrencilerinin gözünden ne olduğunu ortaya çıkarmak amaçlanmıştır. Bu yüzden nitel araştırma desenlerinden olan durum çalışması kullanılmıştır. Araştırma 2018 - 2019 eğitim - öğretim yılı bahar döneminde Türkiye’nin Ege bölgesinde yer alan bir devlet üniversitesinde öğrenim gören 13 Çocuk Gelişimi önlisans öğrencisiyle gerçekleştirilmiştir. Katılımcılar amaçlı örnekleme yöntemlerinden kritik durum örnekleme yöntemine göre belirlenmiştir. 2. sınıf öğrencilerinden 13 katılımcı (6 alt akademik düzeyde ve 7 üst akademik düzeyde olacak şekilde) görüşmeye tabi tutulmuştur. Katılımcıların görüşlerinin alınabilmesi amacıyla kendilerine sorulmak üzere 4 soru belirlenmiştir. Görüşmeler yüz yüze gerçekleşmiş ve yarı yapılandırılmış görüşme formu ile veriler elde edilmiştir. Görüşmeler neticesinde elde edilen veriler görüşme formuna yazılmıştır ve yaklaşık 25 sayfalık görüşme ham verisine ulaşılmıştır. Elde edilen görüşme verileri 3 farklı kişi tarafından kodlanmıştır. Kodlamalardan elde edilen veriler doğrultusunda ortaya çıkan 4 tema kapsamında bulgular açıklanmaya çalışılmıştır. Sonuç olarak, katılımcılar çocuk kavramını farklı anlamlar taşıyan kavramlarla açıklamaya çalışırken, toplumun çocuk ve gelişimi hakkında istenen seviyede bilgi sahibi olmadığını ve çocuklara gereken değerin verilmediğini düşünmektedir. Ayrıca katılımcıların çocuk ve gelişimi hakkında kısmen bilgileri olsa da çocuk gelişimi hakkında detaylı ve etraflı bilgiye sahip olmadığı, programa giriş ve geliş amacının ise temelinde çocuk sevgisinin olduğu tespit edilmiştir.

Anahtar Kelimeler: Eğitim Bilimleri, Çocuk, Çocuk Kavramı, Çocuk Gelişimi, Çocuk Gelişimi Programı 


\section{Giriş}

Hemen hemen her şeyin hızlı bir şekilde değiştiği günümüzde, kültürün, zamanın ve coğrafyanın büyük oranla etki ettiği çocuk ve çocuk algısı da hızla değişmektedir. Çocuk kavramı farklı kültürlerde, toplumlarda ve eğitimde farklı şekillerde tanımlanmıştır. Birleşmiş Milletler Çocuklara Yardım Fonu (UNICEF) çocuğu "Belli bir ülkenin yasaları, yetişkinliğin yasal yaşını küçültmediyse, çocuk 18 yaşın altındaki kişidir" olarak tanımlamaktadır. ${ }^{1}$, yine 1989 yılında Birleşmiş Milletler tarafından onaylanan Çocuk Haklarına Dair Sözleşme'nin birinci maddesinde "Daha erken reşit olma durumu hariç, on sekiz yaşına kadar her insan çocuk sayllır." denilmektedir" ${ }^{2}$ Farklı bir tanımda ise "Ergenlik veya reşit olma yaşının altında olan genç bir insan" şeklinde bahsedilmektedir ${ }^{3}$. Tanımlara bakıldığında yaşın, reşit olma durumunun ve ülkenin yasalarının çocuk kavramına etki ettiği göze çarpmaktadır.

Çocuk tanımına olan ilgi geçmişten günümüze her zaman düşünürlerin, filozofların ve eğitimcilerin ilgisini çekmiştir (Erdiller-Yatmaz, Erdemir \& Erbil, 2018b). Tarihte ilk kez Aries (1962) çocuk ve çocuğun tanımını incelemiş ve bu günden sonra çocuk araştırmalarda özne olarak yer almıştır (Erdiller-Yatmaz, Erdemir ve Erbil, 2018b). Yine çok tartış1lan ve eleştirilen kitabında Aries çocukluğun Rönesans'ın keşfettiği bir buluş olduğunu savunmaktadır. Orta Çağ'da çocukluk kavramının olmadığını, çocukların yetişkinlerin dünyasını her yönüyle paylaştığını ve o dönemde çocukların sanatın hiçbir alanında olmayışının bebeklikten yetişkinliğe bir geçiş döneminin olmadığının kanıtı olduğunu söylemektedir (Onur, 2005). Postman (1995), çocukluğun tanımlanmasında matbaa ve okuryazarlığın etkisi olduğunu düşünmekte buna bağlı olarak da okulun çocukluk çağı olarak geçirilen süreyi artırdığı ve yetişkinlikle arasına bir mesafe koyduğunu belirtmektedir. Başka bir ifadesinde ise okuryazarlığın çocuğun otonomisinin gelişmesi konusunda kısıtlı kaldığı ve özellikle endüstrileşme döneminde yetişkinler ve çocukların aynı bilgiye ulaşabilmesi göz önüne alındığında çocuğa Orta Çağ'daki "minyatür yetişkin" ya da "küçük yetişkin" benzetmesi yapılmaktadır. Yapılan bir çalışmada çocuklar ilgiden ve kendi sesinden mahrum olduğu ve "sesi kısılmış" veya "susturulmuş" bir grup olarak adlandırıldığı ortaya çıkmıştır. Yine aynı araştırmada yetişkinin tersine çocuklara yüklenen "olgun olmayan", "mantık dışı", "yetersiz" gibi ifadeler göze çarpmaktadır (James \& Prout, 1997). Yeni yapılan çalışmalar öncelikle çocukların kendilerine ait bir sesi olduğunu ve hakları olduğunu göstermiş ve bu sesi kısılmış ifadesini ortadan kaldırmaya çalışmaktadır (Kaya, Vural \& Aydın, 2016). Heywood (2003), çocukların ebeveynin bir modeli olmadığını vurgulamış ve çocukların saf, masum, zayıf gibi tabir edilmesinin kültürel ve tarihsel durumla ilişkili olduğunu belirtmiştir. Gelişen dünyayla beraber çocuk yetişkinden ayrı bir özne olarak kabul edilmiştir (Düzcan, 2017).

Çocuklar üzerine ne düşündüğümüzü ve neye inandığımızı onlar hakkında konuşurken kullanılan kelimeler ortaya koymaktadır. Çocukların ayrı bir sınıf olarak görülmesi ve nasıl algılandığı, çocuklardan beklentileri, toplumda çocuğa verilen rolü de göstermektedir (Kaya, Vural \& Aydin, 2016).

Gelişimsel olarak bakıldığında çocuk aslında insanın özüdür ve insanın henüz oluşma sürecinde olan kapasitesini yansıtmaktadır. Çocuk hem iyiliği hem de kötülüğü yapabilme kapasitesini içermektedir. Çocukluk dönemi yetişkinlikten ayrı değerlendirilmesi gereken, benzersiz ve kendine has özellikleri olan bir dönemdir. Çocukluk "olabilecek olanı" yani geleceği temsil eder (Erdiller-Yatmaz, Erdemir \& Erbil, 2018b). Bu yüzden toplumun en önemli güvencesi olan çocuk eğitimi, aydınlık gelecek için gereklidir (Kuyucu, Şahin, Kapıcıoğlu, 2013). Bu durum çocukların evlerinden ilk defa ayrılıp eğitim hayatına başladıkları okul öncesi eğitim kurumlarının rolünü oldukça önemli kılmaktadır (Duran \& Dağlığlu, 2017).

\footnotetext{
${ }^{1}$ https://www.unicef.org/crc/files/Guiding_Principles.pdf

2 https://www.unicef.org/turkey/pdf/_cr23.pdf

${ }^{3}$ https://en.oxforddictionaries.com/definition/child
} 
"Okul öncesi ĕgitim; isteğe bağll olarak zorunlu ilköğretim çağına gelmemiş, 3 yaş (36 ayını dolduran), 4 yaş ve 5 yaş (66 aydan küçük olan) grubundaki çocukların eğitimini kapsar" (MEB Örgün Eğitim İstatistikleri, 2018). Okul öncesi eğitim çocuğun fiziki, psikomotor, sosyalduygusal, bilişsel ve dil gelişimlerine çok büyük ölçüde katkıda bulunan bir dönem olmakla birlikte, bu dönemde kişilik özellikleri büyük oranla şekillenmekte ve çocukta sürekli bir değişim gözlenmektedir (Ömeroğlu \& Yaflar, 2004). Türkiye istatistiklerine göre 2018-2019 öğretim y1lında toplam 31.813 okul öncesi eğitim kurumu ve bu kurumlarda öğrenim gören toplam 1.564.813 öğrenci bulunmaktadır (MEB Örgün Eğitim İstatistikleri, 2018). Bu okul öncesi eğitim kurumlarında okul öncesi öğretmenleri ve çocuk gelişimi lisans mezunları gibi çocuk gelişimi önlisans mezunları da çalışabilmektedir. Çalışma hayatına başlamadan önce Çocuk Gelişimi programı öğrencilerinin çocuk kavramına yüklediği anlamların belirlenmesi son derece önemlidir.

Alanyazın incelendiğinde çocuk ve çocuk oyunları (Aydoğdu \& Ayanoğlu, 2019; Demirbaş, 2015; Egemen, Adil \& Yılmaz, 2004; Ergin, Şahin \& Erişen, 2013; Giren, 2016; Kabaday1, 2016; Saban \& Özcan, 2018; Kuyucu, Şahin \&Kapıc1oğlu, 2013; Pesen, 2015; Ünal, Erdoğan \& Demirhan, 2016;), çocuk gelişimi (Ahioğlu, 2008), çocuk hakları (Kurtdede Özyürek \& Özaydın, 2019), çocuk katılımı (Bektaş, Yavaş \& Can, 2018), çocuk ve demokrasi (Sadık \& Sarı, 2012), çocuk ve öğretmen (Akgün, 2016), çocuk edebiyatı ve çocuk kitapları (Hasırcı, 2013; Pektaş \& Bencik Kangal, 2015; Ulusoy \& Altun, 2018) ve çocuk istismarı (Uysal Bayrak, 2019) gibi kavramlar üzerinde çalışmaların yapıldığı görülmektedir. Alanyazında çocuk kavramına ilişkin farklı çalışmalara rastlansa da çocuk kavramının Çocuk Gelişimi programı öğrencileri tarafından farklı boyutlarıyla değerlendirildiği bir çalışmanın olmaması araştırmanın alana katkı yapacağını düşündürmektedir.

Çocuk gelişimi ve eğitimi ile ilgilenen mesleklerde çocuk algısının ne olduğunun ortaya konması çocuk eğitiminin geliştirilmesi ve bu mesleği icra edecek insanların seçimi konusu son derece önemlidir. Bu araştırmanın amacı da bütün bunlar göz önüne alınarak çocuk gelişsimi önlisans programı öğrencilerinin çocuğa ilişkin düşüncelerini anlamak ve çocuk algısını incelemektir. Bu amaç doğrultusunda aşağıda yer alan sorulara cevap aranmıştır.

1. Çocuk Gelişimi programı öğrencilerine göre çocuk kavramı neyi ifade etmektedir?

2. Çocuk Gelişimi programı ögrencilerine göre toplumda çocuğa verilen değer nasıldır?

3. Çocuk Gelişimi programı öğrencilerine göre çocuk ve yetişkin arasındaki gelişimsel farklar nelerdir?

4. Öğrencilerin Çocuk Gelişimi programını tercih etme sebepleri nelerdir?

\section{Yöntem}

$\mathrm{Bu}$ bölüm altında araştırmanın amacı, modeli, çalışma grubu, veri toplama araçları, verilerin toplanması ve analizi, geçerlilik ve güvenirlik ele alınmıştır.

\section{Araştırmanın Modeli}

$\mathrm{Bu}$ araştırma, nitel araştırma yoluyla tasarlanmış bir durum çalışmasıdır. Literatüre bakıldığında nitel araştırma yöntemlerinden biri olarak değerlendirilen durum çalışması her ne kadar farklı araştırmacılar tarafindan farklı tanımlanıp kategorize edilmişse de ortak noktası bir durumun derinlemesine çalışılıp betimlenmesi olarak ifade edilmektedir (Subaşı \& Okumuş, 2017). $\mathrm{Bu}$ çalışma da Davey (1991)'in sınıflaması dikkate alındığında betimlemeyi amaçlayan açıklayıcı/tanımlayıcı durum çalışması olarak nitelendirilebilir (Gökçek, 2009).

\section{Çalışma Grubu}

Bu çalışma, 2018-2019 eğitim-öğretim yılı bahar döneminde Ege bölgesinde yer alan bir devlet üniversitesinde öğrenim görmekte olan 13 ikinci sınıf Çocuk Gelişimi önlisans programı öğrencisinin görüşleri alınarak gerçekleştirilmiştir. Görüşme yapılan katılımcıların seçiminde 
zaman, çaba ve maliyet kolaylığı açısından uygun örnekleme, özellikle araştırmanın belirli bir bölgeyle sınırlandırıldığı ve zengin bilgi sunduğu için kritik durum örneklemesi yapılmıştır. Çalışma grubunun seçiminde Ege bölgesinde yer alan bir üniversitenin meslek yüksekokulunda yer alan Çocuk Gelişimi programı belirlenmiş; daha sonra gönüllük esas alınarak bu programda öğrenim gören öğrencilerle görüşülmüştür. Görüşmeler sonucunda, katılımcıların tamamının kadın oduğu, biri dışında tamamının 19 yaşında olduğu, çoğunluğunun meslek lisesi mezunu olduğu; katılımcıların annelerinin biri dışında diğerlerinin ev hanımı olduğu, annelerinin ikisi dışında diğerlerinin ilkokul mezunu olduğu; babalarının farklı meslek dallarını icra ettiği ve genel olarak ortaokul mezunu olduğu anlaşılmıştır.

\section{Veri Toplama Aracı}

Araştırmaya ilişkin veriler, araştırmacılar tarafından oluşturulan yarı-yapılandırılmış görüşme formuyla toplanmıştır. Görüşme formunun yapılandırılma sürecinde çocuk, çocuk gelişimi ve çocuk gelişimi programı üzerine literatür ve alan taraması yapılmış, tez ve makaleler incelenmiş ayrıca iki konu alanı uzmanının onayından sonra görüşme soruları oluşturulmuştur. Formun pilot uygulaması Ege bölgesinde yer alan aynı üniversiteye bağlı bir başka MYO bünyesinde yer alan Çocuk Gelişimi önlisans programında öğrenimine devam eden üç öğrenciyle yapılmıştır. Geribildirimler doğrultusunda sorular yeniden değerlendirilerek öğrencilerle görüşmede kullanılacak 4 açık uçlu sorudan meydana gelen yarı-yapılandırılmış bir görüşme formu oluşturulmuştur.

\section{Verilerin Toplanması ve Analizi}

Araştırma kapsamında katılımcılarla yapılan görüşmeler; katılımcıların boş derslerinde ve okul çıkışlarında gerçekleştirilmiştir. Yapılan her bir görüşme ortalama 20-25 dakika sürmüştür. Görüşmeler esnasında katılımcıların ses kaydına izin vermemesinden dolayı bütün görüşmeler not alma şeklinde ve farklı günlerde gerçekleştirilmiştir. Görüşmeler neticesinde 25 sayfalık ham veriye ulaşı1mıştır.

Veriler üzerinde betimsel analiz yapılmıştır. Bu analiz türünde temel amaç elde edilmiş olan bulguların okuyucuya özetlenmiş ve yorumlanmış bir biçimde sunulmasıdır (Yıldırım ve Şimşek, 2003). Bu sebeple görüşmelerden elde edilen veriler, soruların ortaya koyduğu temalar özetlenip tablolaştırılmış ve yorumlanmıştır. Özdemir'in (2010) ifade ettiği üzere bu analiz türünde araştırmacı görüştügü bireylerin görüşlerini çarpıcı bir biçimde yansıtabilmek amacıyla doğrudan alıntılara s1k s1k yer vermektedir.

\section{Geçerlik ve Güvenirlik İçin Yapılan İşlemler}

Araştırmanın geçerliliğini sağlamak için veriler farklı zamanlarda toplanıp bulguların doğruluğu için araştırmacının yanı sıra Ege bölgesinde yer alan aynı üniversiteye bağl Sosyal Bilimler Enstitüsü Eğitim Programları ve Öğretim Anabilim dalında görev yapmakta olan iki öğretim elemanından destek alınmıştır. Verilerin yazımı, tanımlanması ve yorumlanmasında nesnel davranılmıştır. Araştırmanın güvenirlik bağlamında ise; yapılan görüşmelerle yüz yüze ve yakınlık kurularak derinlemesine ve gerçek veri toplanmaya çalışılmış ve elde edilen veriler doğrudan sunulmuş, araştırmacı dışında iki konu alanı uzmanı analiz sürecine katılarak kodlama uyumu ve kodlayıcılar arası uzlaşma puanı hesaplanmıştır. Miles ve Huberman (1994)'a göre kodlayıcılar arası görüş birliğinin en az \%80 olması gerektiği dikkate alındığında; rastgele seçilen iki görüşme formu araştırmacı ve konu alanı uzmanları tarafından kodlandıktan sonra analizler arasındaki tutarlılık (anlaşma/anlaşma+anlaşmama)/100 formülü ile incelenmiş ve uyuşma katsayısı 0,89 olarak bulunmuştur. Ayrıca katılımcılara da K1-K13 arasında kodlar verilerek güvenirlik arttırılmaya çalışılmıştır. 


\section{Bulgular ve Yorum}

Çocuk kavramının Çocuk Gelişimi programı öğrencileri gözünden incelenmesinin amaçlandığı bu çalışmada katılımcıların çocuk kavramına ilişkin düşünceleri, toplum olarak çocuğa gereken değerin verilip verilmediği, çocukların gelişimsel özellikleri dikkate alındığında çocuğun yetişkinin bir küçük modelinin olup olmadığı ve çocuk gelişim programlarına geliş amaçları yapılan görüşmelerle ortaya konmaya çalışılmış; betimsel analiz doğrultusunda 4 tema başlı̆̆ında farklı kategori ve kodlarla verilmiştir. Bunlar çocuk, çocuğa verilen değer, yetişkin çocuk modeli ve programa geliş amacı isimleri altında toplanmıştır.

\section{Tema 1: Çocuk Kavramına Yüklenen Anlamlar}

Kişisel, ruhsal, ahlaki, fiziki gelişimin temellerinin örgün eğitimde anaokulu ve kreş/gündüz bakımevlerinde atıldığı düşünülürse çocuk gelişim programında öğrenim gören katılımcıların çocuk kavramı, çocuğun gelişimi, çocuğun toplumundaki yeri ve önemi, katılımcıların bu programa geliş amaçları gibi düşüncelerinin saptanması önem taşımaktadır. $\mathrm{Bu}$ alanlarda ara elaman ve yardımcı personel olarak hizmet veren çocuk gelişim mezunu bireylerin konu hakkındaki bilgilerinin tespiti bizlere bu alanda çalışan mezunlar için genel bir kanaat oluşturacağı gibi mevcut çalışanlar hakkında da genel bir yargıya varmada yardımcı olacağı düşünülmüştür.

İlk defa mezun verecek olan Çocuk Gelişimi programı 2. sınıf öğrencilerinin çocuğu nasıl algıladıkları, çocuk kavramına hangi anlamları yüklediklerini ortaya koymak adına programda eğitim gören katılımcılara sorulan sorulara verilen cevaplardan çıkarılan üst tema, tema, kategori ve kod listesi Tablo 1'de verilmiştir.

Tablo. 1 Çocuk Kavramına İlişkin Kod, Kategori, Tema ve Üst Tema Listesi

\begin{tabular}{|c|c|c|c|c|}
\hline \multicolumn{5}{|c|}{ Üst Tema, Tema, Kategori, Kod Listesi } \\
\hline $\begin{array}{l}\text { Üst } \\
\text { Tema }\end{array}$ & Tema & Kategori & Kodlar & $f$ \\
\hline \multirow{20}{*}{ Çocuk } & \multirow{19}{*}{ Olumlu } & & Oyun & 3 \\
\hline & & & Oyuncak & 1 \\
\hline & & Maddi & Kumdan kale & 1 \\
\hline & & & Çizgi film & 1 \\
\hline & & \multirow{15}{*}{ Manevi } & Sevgi & 2 \\
\hline & & & Huzur & 1 \\
\hline & & & Kaşif & 1 \\
\hline & & & Mutluluk & 2 \\
\hline & & & Masumiyet & 3 \\
\hline & & & Neşe kaynağ1 & 1 \\
\hline & & & Gelecek & 2 \\
\hline & & & Saflık & 3 \\
\hline & & & Temizlik & 1 \\
\hline & & & Doğallık & 1 \\
\hline & & & Tebessüm & 1 \\
\hline & & & Yaratic1 & 1 \\
\hline & & & Sınırsınız hayal dünyası & 1 \\
\hline & & & Büyüklerin geçmişi & 1 \\
\hline & & & En güzel dönem & 1 \\
\hline & Olumsuz & Maddi & Bakıma muhtaç & 1 \\
\hline
\end{tabular}

Tablo 1'de katılımcıların çocuk kavramına ilişkin görüşleri incelendiğinde çocuk kavramına ilişkin yükledikleri anlamların olumlu olarak maddi ve manevi kategoride olumsuz olarak maddi kategoride toplandığı görülmektedir. Yapılan görüşme neticesinde katılımcıların çoğunluğunun (12) çocuk kavramına olumlu anlam yüklediği ve bu yükledikleri anlamların da kendi aralarında maddi ve manevi olarak iki farklı kategoride toplandığı görülmektedir. 
Çocuk kavramını maddi ve manevi anlamda olumlu olarak ifade eden kat1lımcı görüşlerinden örnekler aşağıdaki gibidir:

"Çocuk, yaratıcı fikirleri olan, hayal dünyasında yaşayan eğlenceli varlıktır. Her çocuk kendi dünyasını oluşturur, yaşar ve ögrenir." (K10)

"Çocuk gelecek nesillerin temelini oluşturan, sevgi ve ilgiye her daim ihtiyact olan bir bireydir. Bunlar da göz önüne alınarak çocuklara öyle davranılması gerekmektedir.”(K11)

“Çocuk bizlerin geçmişidir. Masumiyet, saflık ve mutluluktur. En küçük bir şeyden mutlu olmak ve hiç kötülük bilmemektir. Hayatımın en güzel dönemidir. Ergenliğe atılan adımdan önceki en mutlu anlarımızdır. En güzel ve en özel anılarımızın biriktiği zaman dilimidir." (K13)

Çocuk kavramını maddi anlamda olumsuz olarak ifade eden katılımcı görüşü aşağıdaki gibidir:

"Çocuk gelecektir. Çocuk denilince aklıma her şeye açık masum, öğrenmeye ve bakıma muhtaç belli sorumlulukları olmayan bir hamur gelmektedir." (K9)

\section{Tema 2: Toplumda Çocuğa Verilen Değer}

Toplumun neşe kaynağı, süsü ve en büyük hazinesi olan çocuğa günümüz dünyasında ne kadar değer verildiği çeşitli toplumlarda ve kültürlerde farlılıklar göstermektedir. Çocuğa değer vermek; yetişkin olarak onun her an yanında olduğumuzu hissettirmek, onunla gönül bağı kurmak, ona değer vermek, söz hakk1 vermek, başarabileceği oranda sorumluluk yüklemek, ona birey olarak toplumda yaşama hakkı tanımak ne olursa olsun onun bir çocuk olduğunu bilgisi gerçeğiyle yaklaşmaktır. Ancak doğru, bilinçli ve tutarlı bir toplum iyi yetişmiş çocukların üzerinde yetişir. Toplumda çocuğa verilen değerin öğrenci gözüyle değerlendirildiği bu temada çocuğa toplum olarak değer verilip verilmediği, verilmiyorsa ne gibi önerilerde bulunulabileceğine ilişkin sorulara verilen cevaplardan çıkarılan tema, kategori, kod listesi Tablo 2'de verilmiştir.

Tablo. 2 Toplumda Çocuğa Verilen Değere İlişkin Kod, Kategori ve Tema Listesi

\begin{tabular}{|c|c|c|c|}
\hline \multicolumn{4}{|c|}{ Tema, Kategori, Kod Listesi } \\
\hline Tema & Kategori & Kod & $f$ \\
\hline \multirow{17}{*}{$\begin{array}{l}\text { Çocuğa } \\
\text { Verilen } \\
\text { Değer }\end{array}$} & Yeterli & Bilinçli toplum yapısı & 2 \\
\hline & & Ebeveynlerin egosunu tatmin etme & 1 \\
\hline & Kismen Yeterli & Gelecek kayg1sı & 1 \\
\hline & & Cinsiyet ayrimı & 2 \\
\hline & & Çocuk istismarı & 2 \\
\hline & & Sorumluluk verilmiyor & 1 \\
\hline & & Erken evlilik & 1 \\
\hline & & Çocuk işçiliği & 2 \\
\hline & Yetersiz & Bilinçsiz toplum yapısı & 2 \\
\hline & & Adaletsiz yaşam şartları & 1 \\
\hline & & Çocuk şiddeti & 1 \\
\hline & Öneri & Birey olarak görülmeli & 2 \\
\hline & & Söz hakkı tanınmalı & 2 \\
\hline & & Sorumluluk verilmeli & 1 \\
\hline & & Yanlış yapmalarına müsaade edilmeli & 1 \\
\hline & & Gerçek yaşama hazırlanmalı & 1 \\
\hline & & Kaliteli vakit geçirmeli & 1 \\
\hline
\end{tabular}

Tablo 2'de katılımcıların görüşleri incelendiğinde toplum olarak çocuğa gereken değerin verilmediği anlaşılmaktadır. Katılımcılar toplum olarak çocuğa yeterli düzeyde değer verilme sebebini bilinçli toplum yapısıyla açıklarken, çocuğa tam olarak olmasa da kısmen değer verilmesini ebeveynlerin egosunu tatmin etme, gelecek kaygısı, cinsiyet ayrımı ve çocuk istismarı kavramlarıyla ifade etmişlerdir. Çocuğa yetersiz düzeyde değer verildiğini ya da değer verilmediğini ifade eden katılımcılar ise bu durumun gerekçelerini çocuklara sorumluluk 
verilmemesi, çocukların hala ilkel bir düşüncenin esiri olarak erken evliliğe zorlanması, çocuk işçiliğinin önüne geçilememesi, çocuk şiddetinin yaşanıyor olması gibi kavramlarla açıklarken aslında bunların da arkasında yatan ana nedenin bilinçsiz toplum yapısı ve adaletsiz yaşam şartlarının olduğunu ifade etmişlerdir.

Katılımcılar çocuğun toplumdaki konumunun istenen ve beklenen düzeyde olmadığını ifade ederken çocuğun bir birey olduğunu, çocuğa evde, okulda ve sınıfta söz hakkı tanınması gerektiğini, çocuklara yapabilecekleri, başarabilecekleri oranda sorumluluk yüklenmesi gerektiğini, çocukların gerçek yaşama hazırlanmaları için yanlış yapmalarına, denemelerine izin verilmesi ve çocukların gerçek yaşama hazırlanmaları gerektiğini ayrıca öneri olarak belirtmiştir.

Türk toplumunda çocuğa verilen değerin yeterli olduğunu ifade eden katılımc1 görüşü aşağıdaki gibidir:

"Toplum olarak çocuğa gereken değerin verildiğini düşünüyorum. Türk toplumu çocukların üzerine düşen, onlara değer veren, onların kendi geleceklerinin olduğunu bilen ve aynı zamanda onların da geleceğini düşünen bir toplum yapısındadır." (K2)

Türk toplumunda çocuğa verilen değerin kısmen yeterli olduğunu ifade eden katılımcı görüşlerinden örnekler aşağıdaki gibidir:

“Çocuğa verilen değerin aileden aileye değiştiğini düşünüyorum. Genelde toplumumuzda çok değer verilmiyor. Ĕ̈itim ögretim hayatlarında bile okul yönetimi, ögretmenler, aileler, eş dost ve akrabaların da çocukları değerlendirmedeki kriterleri belli. Onları sadece karnelerine göre, başarı belgelerine göre değerlendiriyor ve çok iyi olduklarını düşünüyoruz. Çok azımız onların eğitim boyutuyla ilgilenip, kendini kötü hissedenlere ve gerçekten kötü olanlart yüreklendirdiğimizi düşünmüyorum." (K6)

"Toplumumuzda çocuğa gereken değerin verildiği kanaatindeyim. Çocuğun geleceği için anne-babalar çalışıp çabalıyor. Aslında verilen değerin de sadece gelecek kaygısıyla, kendi egomuzu tatmin etme hırsıyla, komşu ne der korkusuyla yapıldığının da göz ardl edilmemesi gerekiyor. Ancak eğitim-öğretim anlamında şimdiki ebeveynlerin daha uyanık ve bilinçli olduğunu, çocuklarına nispeten eğitim alanında da olsa gereğinden fazla değer verdiğine şahit olabiliriz." (K10)

Türk toplumunda çocuğa verilen değerin yetersiz olduğunu ifade eden katılımc1 görüşlerinden örnekler aşağıdaki gibidir:

"Bence toplumumuz çocuğa gereken değeri vermiyor. Çocuk istismar ve ihmali çok fazla, çocukların geleceğimiz olduğu bilincinde değiliz bunun yanında cinsel istismarının hala devam ettiğini bile söyleyebiliriz. Erkek çocuğun evlat, klz çocuğun ise üvey evlat olarak görüldüğü sürece toplum olarak çocuklara gereken değerin verilmeyeceğini belirtmek isterim."(K11)

"Kesinlikle toplumumuzda çocuk hak ettiği yerde değil, çocuğa gereken özen gösterilmiyor ve değer verilmiyor. Ĕger çocuklara hak ettĭgi değer verilseydi bazı çocuklar parkta, AVMlerde oynarken bazıları çalışmak zorunda kalmazdı. Ĕ̈itim-öğretim, oyun...her çocuğun hakkıdır ve her çocuk özeldir." (K13)

Türk toplumunda çocuğa verilen değerlere ilişkin öneride bulunan katılımc1 görüşüne örnek aşağıdaki gibidir:

“Çocuğun bakımı ve korunmasını Türk toplumu olarak yeterli görüyoruz. Bu düşünce çok yanlış. Temel ihtiyaçlarını gidermek, onlara bakmak ve korumak onları geleceğe iyi bir vatandaş olarak hazırlamak zaten ebeveynlerin görevi ve çocukların temel ihtiyacı. Bunların yanında onlara da birer birey olarak bakalmall, aile içinde söz hakkı verilmeli, yapabileceği sorumluluklar verilmeli, yanlışlar düzeltilmeli ve hoş görülmeli, onların yanlış yapmalarına müsaade edilmeli yani çocuk gerçek yaşama her anlamda hazırlanmalı ki ilerde biz büyükler yanında olmadı̆̆ımızda 
ne yapabileceğini nasıl davranacă̆ını nasıl çözüm üreteceğini düştüğünde nasıl kalkması gerektiğini, kişisel alanını ve kendini koruyabilsin. Tavsiyem çocukların da birer fikirlerinin olduğu ve bunların kesinlikle dikkate alınmasi gerektiğidir. Bunu yaparsak ve becerebilirsek ne kadar orijinal ve doğal olduklarını ve ne kadar yaratıcı olduklarını da görmemize imkan vermiş oluruz." (K5)

\section{Tema 3: Çocuğun Yetişkinin Küçük Bir Modeli Olup Olmadığı}

Gelişim her anlamda değerlendirilecek olursa, çocuğun yetişkinin bir modeli olmadığını görmek mümkündür. Piagete'e göre çocuğun duyusal-motor dönemi (0-2), işlem öncesi dönem (26) ve somut işlemler dönemi (7-11) ve soyut işlemler döneminde (11 yaş ve üzeri) ${ }^{4}$ olduğu düşünülürse bir yetişkinle aynı şeyleri düşünemeyeceği, bir kavrama ve olguya özellikle soyut bir kavram veya olguya aynı anlamı yükleyemeyeceği aşikârdır. Bu genellemeyi ahlaki gelişim, dil gelişimi veya duygusal gelişim için de söylemek mümkündür.

Çocuğun gelişimsel özellikleri dikkate alındığında bir yetişkinin küçük bir modeli olup olmadığı, modeli ise hangi sebeplerden dolayı bir yetişkinin modeli olduğu, modeli değilse neden bir yetişkinin modelinin olmadığının araştırıldığı bu temada katılımcılarla yapılan görüşmelerden elde edilen verilerden çıkarılan tema, kategori ve kod listesi Tablo 3 'te verilmiştir.

Tablo. 3 Çocuğun Yetişkinin Küçük Bir Modeli Olup Olmadığına İlişkin Kod, Kategori ve Tema Listesi

\begin{tabular}{llll}
\hline \multicolumn{4}{c}{ Tema, Kategori, Kod Listesi } \\
\hline Tema & Kategori & Kod & $f$ \\
\hline Çocuğun Yetişkinin Küçük Bir Modeli & Evet & Rol model olma & 11 \\
Olup Olmadığ1 & Hayır & Gelişim dönemleri & 2 \\
\hline
\end{tabular}

Tablo 3'e göre katılımcıların tamamına yakınının çocuğun yetişkinin bir modeli olduğu görüşündedir. Bunun gerekçesi olarak çocuğun bir yetişkini, ebeveynini örnek aldığı, onları rol model olarak gördüğü bu sebeple seçtiği yetişkin gibi düşünüp davrandığı, rol model olarak seçtiği yetişkin gibi giyindiği, beslendiğini ifade ettikleri belirlenmiştir. Katılımcılardan yalnızca ikisi, çocukların bir yetişkinin modelinin olmadığını bu durumun gerekçesi olarak yetişkinle çocuğun gelişim dönem ve evrelerinin farklı olduğunu beyan etmişlerdir. Çocuğun yetişkinin bir modelinin olmadığını ifade eden bir katılımcı ise çocuğun duyusal-motor işlemi döneminde olduğunu çarpıcı bir şekilde ifade etmiştir.

Çocuğun yetişkinin küçük bir modeli olduğunu ifade eden katılımcı görüşlerine örnek aşağıdaki gibidir:

"Çocukların gelişimi dikkate alındığında çocuk yetişkinin bir küçük kopyasıdır. Kızlar 3-4 yaşındayken annedir çünkü kı çocukları anneye benzemek ister. Erkek çocukları ise babaya benzemek ister çünkü babasinın en güçlü ve her şeyi bildiğini düşünür. Okul öncesinde ise kızlar evde en çok annesiyle vakit geçirdiği için annesi olmak ister anneyi rol model alır.

Çocuklar okula başladığında birden eksen kayması başlar ve odak nokta öğretmene çevrilir. Çünkü zamanın çoğu onunla geçirilir. Bu sebeple çocuklar da ögretmenleri gibi davranmaya onun gibi giyinmeye ve onun gibi tavır sergilemeye başlar. Kısacası okul öncesi anne baba okul döneminde ise öğretmenin küçük birer modelidirler." (K1)

"Çocukların gelişimsel özellikleri dikkate alındığında aslında çocuklar yetişkinlerin küçük modelidir. Çünkü biz çocuklara nasıl eğitim verirsek nasıl yönlendirirsek öğrettiklerimizle yoğrulup şekillenirler. Bu yüzden çocuklar çoğu zaman anne babaların taklit ederler. Bunun için anne babalardan önce kendilerini eğitmelidirler ki sağlıklı bireyler yetiştirebilsinler." (K4)

\footnotetext{
${ }^{4}$ https://ustunzekalilar.org/tr/Makaleler/Icerik/1299-Piaget-In-Bilissel-Gelisim-Kurami
} 
"Evet çocuklar yetişkinlerin küçük modelidir. Bir anne veya baba çocuğun bir problemi olduğunda suçlayıcı bir tavır sergilerse çocuk büyüdü̈̆̈̈nde veya arkadaş çevresine, oyuncağına anne ve babasına davrandı̆̆ gibi davranır. Ĕger anne ve baba problemi çözümleyici bir tavır sergilerse çocuk da arkadaş veya oyuncaklarına sorunu gidermeye, ılıml davranıs sergiliyor. Çocuk anne ve babasının davrandı $\breve{g}$ gibi davranmaya çalışıyor. Yani çocuk anne ve babasından nasll bir ilgi görüyorsa hayal dünyasl da onlar gibi oluyor. "(K5) gibidir:

Çocuğun yetişkinin küçük bir modeli olmadığını ifade eden katılımcı görüşleri aşağıdaki

"Çocuk yetişkinin küçük bir modeli değildir. Piaget'e göre ilk duyu-motor evresinde çevresini keşfeden meleklerdir." (K3)

"Çocuklar yetişkinlerin küçük modeli değillerdir. Çünkü çocukların dünyaya bakış açıları, hayal dünyaları büyüklerin dünyasından çok farklıdır. Buna bağll olarak sorumluluk ve istekleri de farklıdır. Çocuklara bunlar göz önünde bulundurularak yaklaşılmalıdır. ”(K11)

\section{Tema 4: Katılımcıların Programı Tercih Etmesinin Çocukla İlgisi}

Bireylerin okuduğu veya okumuş olduğu bölüm/programı tercih etmek için farklı nedenleri vardır. Bazen isteyerek ve bazen de zorunluluklar nedeniyle bölüm/programa devam edebilmektedir. Genellikle gelecekte sunacağı iş imkanı, kariyer planı, ekonomik getirisi, aile ve çevre baskısı gibi sebeplerden dolayı öğrenim görülen bölüm/program tercih edilebilmektedir.

Çocuk Gelişimi Programında öğrenim gören katılımcıların programı tercih etme sebeplerinin ve amaçlarının öğrenci gözüyle değerlendirildiği bu temada Çocuk gelişimi Programını hangi gerekçelerle ve hangi amaçla tercih ettikleri sorularına verilen cevaplardan çıkarılan tema, kategori, kod listesi Tablo 4'te verilmiştir.

Tablo 4: Öğrencilerin Programı Tercih Etme Amacına İlişkin Kod, Kategori ve Tema Listesi

\begin{tabular}{|c|c|c|c|}
\hline \multicolumn{4}{|c|}{ Tema, Kategori, Kod Listesi } \\
\hline Tema & Kategori & Kod & $\mathbf{f}$ \\
\hline \multirow{6}{*}{$\begin{array}{l}\text { Öğrencilerin Programı } \\
\text { Tercih Etme Amacı }\end{array}$} & & Kariyer planı & 4 \\
\hline & Meslek & Mesleki yeterlik inancı & 1 \\
\hline & Çocuk & Çocuk sevgisi & 9 \\
\hline & & Hobi\&Eğlence & 2 \\
\hline & Kişi & İdealler & 1 \\
\hline & & Zorunluluk & 1 \\
\hline
\end{tabular}

Tablo 4'te katılımcıların Çocuk Gelişimi Programını tercih sebepleri mesleki, çocuk ve kişi bazında genel olarak değerlendirilmiştir. Programı tercih etme sebepleri genel olarak çocuk sevgisi, idealler, kariyer planlarının ilk ayağını oluşturması, bu mesleği yapabileceklerine inanma, mesleği yapabileceğinin yanında bu mesleği bir iş olarak değil bir hobi olarak görme, mesleğini zorunluluktan değil eğlenerek yapacağına inanma ve bu bölümü puanı yettiği için veya iş imkanından dolayı tercih etme olduğu görülmektedir.

Çocuk Çelişimi Önlisans Programını tercih etme amacını mesleki açıdan değerlendiren katılımcı görüşlerine örnek aşağıdaki gibidir:

“Çocuklarla iyi iletişim kurabileceğimi düşündüğüm için bu bölümü seçtim.”(K2)

"Çocukların gelişim düzeylerinin iyi bir şekilde bilmek, çocukları gözlemlemek ve çocuk gelişim bölümünde akademisyen olabilmek için bu bölümü tercih ettim. (K6)

Çocuk gelişimi önlisans programını tercih etme amacını çocuk açısından değerlendiren katılımcı görüşlerine örnek aşağıdaki gibidir: 
"Çocuk gelişimi seçme sebebim; çocukları çok sevmem ve gelecekte iyi bir anne ve eğitimci olmayı hedeflediğim için bu bölümü bilerek ve isteyerek tercih edip geldim. Bazı annelere ve okul öncesi öğretmenlerine örnek olmak için bu bölümü tercih ettim." (K9)

"Çocukları sevmem ve onlarla ilgilenmek hoşuma gittiği için bu programı seçtim ama zamanla bu programı seçtiğime pişman olduğum zamanlar da oluyor. Bunun nedeni çocuklar değil başka insanların bizleri bu meslekten soğutması.(K12)

Çocuk gelişimi önlisans programını tercih etme amacını kişisel açıdan değerlendiren katılımcı görüşlerine örnek aşağıdaki gibidir:

"Puanım bu bölüme yettiği için bu bölümü tercih ettim. (K5)

"Bana eğlenceli geliyor. Etkinlik yapmak zevkli. Güzel vakit geçiriyorum. Çocuklar umut verici. Özellikle mutsuzken kendimi çocukların yanında huzurlu ve mutlu hissediyorum.” (K10)

\section{Sonuç ve Tartışma}

$\mathrm{Bu}$ çalışmada Çocuk Gelişimi programı öğrencileri gözünden çocuk kavramı-nitel araştırma deseninde incelenmiştir. Çocuk kavramına yüklenilen anlamlar, toplumda çocuğa verilen değer, çocuğun yetişkinin küçük bir modeli olup olmadığı ve öğrencilerin programı tercih etme amacı adı altında 4 tema ve farklı kodlar altında toplanan veriler betimsel analiz sonucunda aşağıdaki sonuçlara ulaşılmıştır.

Çocuk kavramına yüklenen anlamlara ilişkin görüşleri alınan katılımcılar çocuk kavramını; oyun, oyuncak, kumdan kale, çizgi film, sevgi, huzur, mutluluk, masumiyet, evin neşe kaynağı, toplumuzun geleceği, saflık, temizlik, doğallık, tebessüm, yaratıcılık ve sınırsız hayal dünyası, büyüklerin özlemle yad ettiği geçmişleri, insan hayatının en güzel ve özel dönemi gibi kavramlarla açıklamaktadırlar. Sadece bir katılımcının çocukların tek başlarına hayatlarını idame ettirmede zorlanacakları, tek başlarına yetişkin hale gelene dek ebeveyn veya bir yetişkinin bakımına muhtaç olduğunu ifade eden bakıma muhtaç kavramlarıyla açıklanmıştır. Literatür incelendiğinde benzer araştırma sonuçları göze çarpmaktadır. Kuyucu, Şahin ve Kapıcıoğlu (2013)'nun yapmış olduğu çalışmada, okul öncesi öğretmenlerinin çocuk kavramını benzer kavramlarla açıkladığı, "hamur, boş bir kaset, ayna, çiçek, melek, ruhun gıdası, ağaç, bilgisayar, kamera ve teyp, sevgi, yıldız, defter, elmas ve mücevher, donmamış beton, aç insan, sünger, açılmamış tertemiz mektup, gizli kutu, hazine, gelecek, ayçiçeği, sevimli bir maymun, tablo, teknoloji, gökkuşağ1, toprak, kutsal mekan, 1ş1tt1, su, maya, rüya, uçurtma, yemek malzemesi, mahsul, gülücük, komedyen, enerji bombası, huzur, özgür ruh, hücre, yanl1, dört mevsim, beyin firtınası, deniz, uzay, özel bir alet ve kaktüs" olarak betimlediği görülmektedir.

Ortaçağda çocukluk kavramının olmadığını, çocukluk kavramının 17. yüzyılda çıktığını ifade eden Aries (1960) çocukluğun olmaması iddiasını çocukluk duygusu ile açıklayarak ortaçağda oyun, oyuncak, çocuklara özgü giysi ve besin olmamasıyla kanıtlamıştır (Onur, 2005). Aries'in çocukluk duygusu kavramını altını doldurduğu kavramlara bakıldığında yapılan araştırmaya paralel sonuçlar elde ettiğini söylenebilir.

Çelik ve Çat (2018) çocuk algısına yönelik kavramları 10 farklı temada inceleyerek benzer sonuçlara ulaşmışlardır. Genel olarak bakıldığında çocuk kavramının; masumiyet, büyütülmesi kontrol edilmesi gereken varlık, evin huzuru, evin aynası, cevher, şekil almamış hamur, sorumluluk, risk vb. kavramlarla açıklanmıştır.

Erdiller-Yatmaz, Erdemir ve Erbil (2018b)'in yaptıkları çalışmada sıfatlarla çocuk kavramını açıklayan kavramlar olarak; tatlı, şirin, sevimli, masumluk, saf, temiz, yaramaz, yaramazlık, oyun, oyun oynayan, zeki, çok akıllı, minik, küçük, çevresi üzerinde yaptırımı olan, çok kolay etkileyebilen, afacan, merak, ön yargısız, özü sözü ya da dürüst, rengarenk, özgürlük, 
mutluluk, yetişkinliğe hazırlanan, el becerisi çok gelişmemiş, ısrarc1, hevesli, hayalperest, hareketli, inatçı ve duygusal kavramlarını tespit etmişlerdir.

Türk toplumunda çocuğa verilen değerlere ilişkin olarak katılımcılar genel anlamda toplum olarak çocuğa gereken değerin verilmediğini ifade etmişlerdir. Görüşmeler neticesinde çocuğa verilen değerin sosyoekonomik yapıyla çok da bir ilgisi olmadığı sonucuna varılabilir. Çünkü katılımcılar çocuğa verilen değerin yeterli düzeyde olma sebebini bilinçli toplum ve aile yapısıyla açıklamaktadırlar. Bunun yanında katılımcıların sosyoekonomik durumu iyi olan ailelerin arasından da çocuğundan genel anlamda sadece akademik başarı beklemesi, kendi egosunu tatmin etme, komşum ne der, elalem ne der endişesiyle çocuğuna bir yarış atı muamelesi yapması sosyoekonomik düzeyin çocuğa verilen değerle bir ilgisinin olmadığını ifade etmişlerdir.

Tezel Şahin ve Cevher (2007)'in yapmış olduğu çalışma sonuçlarına göre, geçmişle karşılaştırıldığında ebeveyn-çocuk iletişiminin bilinçlendiği, çocuğa karşı daha olumlu tutumlar sergilenmeye başlandığı; ancak hala çocuklara faydacı bir değer yüklenmeye çalışılmaya devam edildiği, bunun yanında sosyoekonomik düzeye göre ebeveynlerin çocuğun eğitimine ve kişilik gelişimine daha çok değer verdiği anlaşılmaktadır. Yazarlar çocuğa gereken değerin verilmeme sebeplerini ise cinsiyet ayrımı, çocuk işçiliği, erken evlilik, çocuk şiddeti gibi hususların devam ediyor olması ile açıklamışlardır. Bu sebeplerin bilinçsiz toplum ve aile yapısından kaynakladığı ifade edilebilir.

Çocuğa verilmesi gereken değerin yeterli seviyede olmamas1 sebebiyle katılımc1lar; çocuğun toplumuzdaki konumunun istenen ve beklenen düzeyde olmadığını ifade ederken, çocuğun bir birey olarak görülmesi gerektiğini, çocuğa evde, okulda ve sınıfta söz hakkı tanınması gerektiğini, çocuklara yapabilecekleri, başarabilecekleri oranda sorumluluk yüklenmesi gerektiğini, çocukların gerçek yaşama hazırlanmaları için yanlış yapmalarına, denemelerine ve gerçek yaşama hazırlanmaları için çocuklara fırsat tanınması gerektiğini ifade etmişlerdir. Çalışmalar neticesinde çocuğa verilen değerin artırılmasına ilişkin olarak çocuk bir birey olarak görülüp öyle davranılması gerekmektedir.

Çocuğun yetişkinin küçük bir modeli olup olmadığına ilişkin görüşmelerde katılımcılardan neredeyse tamamının çocuğun yetişkinin bir modeli olduğu görüşünde oldukları belirlenmiştir. Katılımcıların, çocuğun gelişimsel özelliklerini dikkate alındığında tamamına yakının verdiği cevaplar gelişim, gelişim psikolojisi ve öğrenme gibi ders içeriklerinde sunulan bilgileri aksine görüşler olduğu söylenebilir. Erdiller-Yatmaz, Erdemir ve Erbil (2018b)'in yapmış olduğu çalışma da çocukların gelişimsel, fiziksel, bakım ihtiyacı ve bağımlılı̆̆ı, öğrenme ve tecrübe, davranışlar ve kısıtlama, direnç ve 1srarcılık, kendilerini ifade etme ve ihtiyaçlarını belirleme gibi sebeplerden dolayı bir çocuğun bir yetişkinle aynı olamayacağını ifade etmektedir. Çocuk ve yetişkinler her alanda birbirinden ayrılması ve düşünülmesi gereken bireylerdir. Çocuğun bir yetişkini rol model alması gelişim dönemleri içerisinde normal karşılanırken, yetişkinlerin çocuğu yetişkinin bir alt modeli gibi görmesi olumsuz durumlar doğurabilir. Bu açıdan çocuğa yalnızca çocuk gibi davranılmalıdır.

Katılımcıların programı tercih sebepleri mesleki, çocuk ve kişi bazında genel olarak değerlendirilmiş ve çocuk sevgisi, idealler, kariyer planlarının ilk ayağını oluşturması, bu mesleği yapabileceklerine inanma, mesleği yapabileceğinin yanında bu mesleği bir iş olarak değil bir hobi olarak görme, mesleğini zorunluluktan değil eğlenerek yapacağına inandıklarından dolayı ve bu bölüme puanı yettiği için veya iş imkanından dolayı tercih etmeleri sonuçlarına ulaşılmıştır. Thomson ve arkadaşları (2011) öğretmenlik mesleğini tercih etme sebeplerini sosyokültürel bağlam, öğretmenlik algısı ve öğretmenlik mesleğini seçme motivasyonu olarak açıklarken, Holland (1985) ve Roe (1957) meslek seçiminde aile, çevre ve genetik faktörlerin etkileşimi neticesinde gelişen kişisel ihtiyaçlar ve tercihlerin belirlediğini ifade etmektedir. Kyriacou ve Coulthard (2000) öğretmenlik mesleğini seçmede en etkili olan üç faktörü; gençlerle çalışma şansı, topluma katkıda bulunabilecek bir meslek olması ve kişiye sorumluluk yükleyen bir meslek olması 
şeklinde belirlemişlerdir. Diğer taraftan Thomson ve arkadaşları (2011), meslek seçimine temel oluşturan altı faktör ileri sürmüş ve bunları içsel motivasyon, işin getirdiği imkanlar, kurulan anlamlı ilişkiler, özgecil görüşler, beceri/yetenek ve firsatlar/olanaklar olarak ifade etmiştir.

Manuel ve Hughes (2006), öğretmen adaylarının öğretmen olma kararlarını etkileyen faktörleri sekiz temel başlıkta ele almış ve kişisel doyum, öğretecekleri alanı sevme, gençlerle çalışmayı sevme, yaşam tarzı, çalışma koşulları, mesleki konum, kazanç ve getirdiği güç olarak sıralamıştır. Öğretmen adaylarının meslek seçimindeki temel nedenlere bakıldığında özgecil düşünce, içsel motivasyon ve ekonomik sebepler olduğu anlaşılmaktadır (Court, Merav \& Ornan, 2009). Erdiller-Yatmaz, Erdemir ve Erbil (2018a) ise meslek seçimini bireyin eğilimleri, ihtiyaçları, esinlenmeleri, mizacı ve eğitimi gibi içsel motivasyonları ile ebeveynler, arkadaşlar, öğretmenler, bilgi kaynakları ve zamanlama gibi dışsal motivasyonlar arasında gerçekleşen bir ödün verme süreci olarak ifade ederken, meslek seçiminde bireylerin hayatında anahtar rolü oynayan anne-baba, bir uzmanla tanışma ve kişisel deneyimlerin olduğunu ifade etmektedir. Bireyler meslekleri ile bütünleşmek zorundadırlar ve çocuk gelişimi ve eğitim alanındaki mesleklerde çocuk sevgisi olmadan mesleklerini icra edebilmek oldukça zordur. Bu açıdan öğrenim dönemlerinde öğrencilerin alan uygulamaları ve stajlarla çalışma hayatına atılmadan önce mesleklerini bir de bu açıdan tanımak hiç şüphesiz önemlidir.

Sonuç olarak, Çocuk Gelişimi programı öğrencilerinin çoğu çocuk kavramını olumlu ifadelerle açıklamışlardır. Katılımcılar toplum olarak çocuğa verilen değer konusunda birtakım eksiklikler olduğunu belirtirken, yetişkinlerin çocuklara rol model olduğunu ifade etmişlerdir. Katılımcıların programa geliş amacının başta çocuk sevgisi olduğu ve çoğunun olumlu duygularla programı tercih ettiği görülmüştür. Bu sonuçlar da göz önünde bulundurulduğunda bazı önerilerde bulunulabilir.

- Programa gelen öğrencilerin hazırbulunuşluğu, mesleki yatkınlığı, mesleki tutumları belirlenmeli ve bu konularda seminerler gibi çeşitli bilimsel aktiviteler düzenlenerek desteklenmelidir.

- Programa geliş amacı farklı olan öğrenciler için meslek sevgisi ve çocuk sevgisini aşılayan eğitimler/etkinlikler düzenlenebilir.

- Okul öncesi eğitim kurumlarının kritik bir öneme sahip olması nedeniyle, bu kurumlarda görev alacak olan çocuk gelişimi ön lisans, lisans ve okul öncesi öğretmenliği programlarına nitelikli öğretim elemanlarının seçimine özen gösterilmelidir.

- Öğretim elemanlarının yeterlikleri sürekli olarak değerlendirilmeli, kendilerini sürekli olarak geliştirebilecekleri alanlarda hizmet içi eğitim almaları özendirilmelidir.

- Programda öğrenim gören öğrencilerin çocuk gelişimine (bilişsel, duyuşal, vb.) ilişkin görüşleri dikkate alındığında özellikle çocuk gelişimi konularının ve derslerinin daha özenli işlenmesi önerilebilir.

\section{Kaynakça}

Akgün E. (2016). Okul öncesi öğretmen adaylarının "çocuk" ve "okul öncesi öğretmeni”" kavramına ilişkin metaforik algıları. Abant İzzet Baysal Üniversitesi Eğitim Fakültesi Dergisi, 16(4), 1652-1672.

Ahioğlu, E.N. (2008). Kültürel-tarihsel kuram çerçevesinde çocuk gelişimi. Ankara Üniversitesi Ĕ̈itim Bilimleri Fakültesi Dergisi, 41(1), 163-186. 
Aydoğdu, F. \& Ayanoğlu, M. (2019). Ortaokulda görev yapan öğretmenlerin "suriyeli çocuk" kavramına ilişkin metaforik algılarının incelenmesi. Uluslararası Mardin Artuklu Multididpliner Çalışmalar Kongresi, Sosyal Bilimler Tam Metin Kitabı, 274-282.

Baykan, S. (2011). “Tarihte Toplumlar”, Değişim Sosyolojisi Dünyada ve Türkiye'de Toplumsal Değişme, Sosyoloji Yıllığı 21, Ed. Ertan Eğribel Ufuk Özcan, İstanbul Kitabevi, (123130), ss. $126-127$.

Bektaş, M., Yavaş, M. \& Can, A.A. (2018). Sınıf öğretmeni adaylarının "çocuk katılımı" kavramına yönelik metaforik algılarının farklı değişkenler açısından incelenmesi. Turkish Studies, 13(19), 253-284.

Brown, S.J. \& Edwards, E.P. (1972). History and theory of early childhood education. Charles A. Jones Yayın Şirketi.

Court, D., Merav, L. \& Ornan, E. (2009). Preschool teachers' narratives: a window on personal: rofessional history, values and beliefs. International Journal of Early Years Education, 17(3), 207-217.

Çelik, E. \& Çat, F.B. (2018). Toplumda değişen çocuk algısı, eğitim yöntemleri ve internetin etkilerine yönelik nitel bir araştırma. Akademik Incelemeler Dergisi (AID), 13(2), 265-300.

Demirbaş, E.K. (2015). Çocuk gelişimi bölümü üniversite öğrencilerinin "çocuk" kavramına ilişkin sahip oldukları zihinsel imgeler. Ĕgitim ve Öğretim Araştırmaları Dergisi, 4(1), 295-303.

Duran, A. \& Dağlığlu, H.E. (2017). Okul Öncesi Öğretmen Adaylarının Üstün Yetenekli Çocuklara İlişkin Metaforik Algıları. GEFAD, 37(3). 855-881.

Düzcan, E. (2017). Çocuk Gözüyle Anlatmak: Sinemada Çocukluğun Büyüme Serüveni. TRT Akademi, 2(4), 398-417.

Egemen, A., Y1lmaz, Ö. \& Akil, İ. (2004). Oyun, oyuncak ve çocuk. ADÜ Tıp Fakültesi Dergisi, $5(2), 39-42$.

Erdiller-Yatmaz, Z.B., Erdemir, E. \& Erbil, F. (2018a). Çocuk ve Çocukluk: Okulöncesi Öğretmen Adayları Anlatıyor. Ĕgitimde Nitel Araştırmalar Dergisi, 6(3), 284-312.

Erdiller-Yatmaz, Z.B., Erdemir, E. \& Erbil, F. (2018b). Okulöncesi öğretmen adaylarının bakış açısından: Neden öğretmenliği seçtiler ve nasıl çocuk/çocukluk algıları var. Kuramsal Eğitimbilim Dergisi [Journal of Theoretical Educational Science], 12(1), 316-341.

Ergin, B., Şahin, M. \& Erişen, Y. (2013). Prospective pre-school teachers' perceptions of "child": A study of metaphors. International Journal on New Trends in Education and Their Implications, 4(4), 88-101.

Follari, L. M. (2011). Foundations and best practices in early childhood education: History, Theories and approaches to learning. Upper Saddle River, Pearson Education.

Giren, S. (2016). Early childhood education teachers' metaphors about play concept for preschoolers/okul öncesi öğretmenlerinin "okul öncesi dönem çocuğu için oyun" kavramına ilişkin metaforları. Eğitimde Kuram ve Uygulama, 12(1), 372-388.

Gökçek, T. (2009). Durum Çalışması Değerlendirmelerinin Uygulaması.(Çeviri: The Application of Case Study Evaluations). Illköğretim Online, 8(2), 1-3.

Hasırcı, S. (2017). Türkçe öğretmeni adaylarının çocuk edebiyatına ilişkin algılarının metaforlar aracılığılla analizi. Uluslararası Sosyal Araştırmalar Dergisi, 10(51), 717-728. 
Heywood, C. (2003). Baba Bana Top At: Batıda Çocukluğun Tarihi. Esin Hoşsucu (çev.). Kitap Yayınevi.

Holland, J.L. (1985). The self-directed search: A guide to educational and vocational planning1985 revision. Psychological Assessment Resources.

James, A. and Prout A., (1997). Constructing and Reconstructing Childhood. Routledge.

Kabaday1, A. (2016). Teachers' metaphorical images on "counting jingle-it-playground" in children's plays of Turkish culture $<\mathrm{p}>$ Türk kültüründeki çocuk oyunlarında "saymacaebe-oyun alanı" üzerine öğretmen metaforları. Journal of Human Sciences, 13(2), 32523265 .

Kaya, A., Vural, G. \& Aydın, A. (2016). Değerler Eğitimi Eğitimde Farklılık ve Katılım Hakkı. İn: Erbil, F. Çocuk Algısı ve Çocuk Katılımı. İstanbul Bilgi Üniversitesi.

Kuyucu, Y., Şahin, M. \& Kapıcığlu, M.O. (2013). Okul Öncesi Öğretmenlerinin "Çocuk" Kavramına İlişkin Sahip Oldukları Zihinsel İmgeler. Eğitim ve Öğretim Araştırmaları Dergisi, 2(2), 43-53.

Kurtdede Fidan, N. \& Özaydın, A. (2019). Ebeveynlerin çocuk haklarına ilişkin metaforik algıları. Nevşehir Hacı Bektaş Veli Üniversitesi SBE Dergisi, 9(2), 361-378.

Kyriacou, C. \& Coulthard, M. (2000). Undergraduates' views of teaching as a career choice. Journal of Education for Teaching, 26(2), 117-126.

Manuel, J. \& Hughes, J. (2006). 'It has always been my dream': Exploring pre-service teachers' motivations for choosing to teach. Teacher Development, 10(1), 5-24.

Miles, M,B. \& Huberman, A.M. (1994). Qualitative data analysis: An expanded Sourcebook. (2nd ed). Thousand Oaks, Sage.

Özdemir, M. (2010). Nitel Veri Analizi: Sosyal Bilimlerde Yöntembilim Sorunsalı Üzerine Bir Çalışma. Eskisehir Osmangazi Üniversitesi Sosyal Bilimler Dergisi, 11(1), 323-343.

Onur, B. (2005a). Türkiye'de Çocukluğun Tarihi, İmge Kitabevi.

Onur, B. (2005b). Çocukluğun dünü ve bugünü. Kebikeç Dergisi, 19, 99-112.

Pektaş, D. \& Bencik Kangal, S. (2015). Okul Öncesi Dönem Resimli Çocuk Kitaplarındaki Dil Sanatlarının İncelenmesi. Uluslararası Katılımlı III. Çocuk Gelişimi ve Eğitimi Kongresi "Erken Müdahale" Hacettepe Üniversitesi.

Pesen, A. (2015). Ebeveynlerin "çocuk" kavramına yükledikleri metaforlar. Turkish Studies, 10(15), $731-748$.

Postman, N. (1995). Çocukluğun Yokoloşu. Kemal İnal (çev.). İmge.

Roe, A. (1957). Early determinants of vocational choice. Journal of Counseling Psychology, 4(3), 212-217.

Saban, A.İ. \& Özcan, Ş.E. (2018). Okulöncesi öğretmenlerinin yaratıcı çocuk algıları: metaforlar aracılığıyla bir incelenme. II. Uluslararası Multidisiplinler Çalışmaları Kongresi Bildiri Tam Metin Kitabl, 80-99.

Sadık, F. \& Sarı, M. (2012). Çocuk ve demokrasi: İlköğretim öğrencilerinin demokrasi algılarının metaforlar aracılığıyla incelenmesi. Cumhuriyet Uluslararası Ĕ̈itim Dergisi, 1(1), 48-62.

Sağlam, İ. (2001). Çocuklarda davranışların şekillenmesinde etkili olan faktörlere teorik bir yaklaşım. Uludağ Üniversitesi Illâhiyat Fakültesi, 10(2), 209-223. 
Subaş1, M. \& Okumuş, K. (2017). Bir Araştırma Yöntemi Olarak Durum Çalışması. Atatürk Üniversitesi Sosyal Bilimler Enstitüsü Dergisi, 21(2), 419-426. http://dergipark.gov.tr/ataunisosbil/issue/34503/424695.

Fatma, T.Ş. \& Cevher, F.N. (2007). Türk Toplumunda Aile-Çocuk İlişkilerine Genel Bir Bakış. ICANAS 38 (38. Uluslararası Asya ve Kuzey Afrika Çalışmaları Kongresi). Atatürk Kültür, Dil ve Tarih Yüksek Kurumu.

Thomson, M.M., Turner, J.E. \& Nietfeld, J.L. (2011). A typological approach to investigate the teaching career decision: Motivations and beliefs about teaching of prospective teacher candidates. Teaching and Teacher Education, 28(3), 324-335.

Ulusoy, M. \& Altun, D. (2018). Okul öncesı öğretmen adaylarının çocuk edebiyatı ve resimli çocuk kitapları ile ilgili metaforları. Elektronik Sosyal Bilimler Dergisİ, 17(67), 1206-1221.

Uysal Bayrak, H. (2019). Ebeveynlerin gözünden çocuk istismarı: Metaforik bir çalışma. Toplum ve Sosyal Hizmet, 30(2), 376-389.

Ünal, D., Erdoğan, D.G. \& Demirhan, E. (2016). Bilsem'nde öğrenim gören çocukların anne ve babalarının üstün yetenekli çocuk kavramına dair metaforik algıları. Eğitim ve Öğretim Araştırmaları Dergisi, 5, 266-274.

Yıldırım, A. \& Şimşek, H. (2003). Sosyal Bilimlerde Nitel Araştırma Yöntemleri. Seçkin Yayınları.

\section{İnternet Kaynakları}

THE CONVENTION ON THE RIGHTS OF THE CHILD Guiding principles: general requirements for all rights https://www.unicef.org/crc/files/Guiding_Principles.pdf (Erişim Tarihi: 07.04.2019)

Çocuk Haklarına Dair Sözleşme https://www.unicef.org/turkey/pdf/_cr23.pdf (ErişimTarihi:09.04.2019)

https://en.oxforddictionaries.com/definition/child (Erișim Tarihi: 10.04.2019)

MEB. (2018). Millî Eğitim İstatistikleri, Örgün Ĕgitim National Education Statistics Formal Education.

http://sgb.meb.gov.tr/meb_iys_dosyalar/2019_09/30102730_meb_istatistikleri_orgun_egiti m_2018_2019.pdf (Erişim Tarihi: 09.05.2019) 